\title{
Early surgical debridement and fixation for pyogenic lumbar spondylodiscitis
}

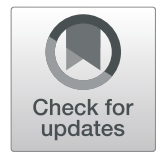

\author{
Mohamed Ibrahim Refaat ${ }^{*}$ and Omar Y. Abdallah
}

\begin{abstract}
Background: Management of pyogenic lumbar spondylodiscitis still represent a major conflict and challenge in neurosurgery due to different pathogens and the different methods available for management.

Objective: The aim of this study was to evaluate the outcome of posterior lumbar spinal fixation with debridement as a treatment modality in the management of pyogenic lumbar spondylodiscitis.

Patients and method

This is a prospective study conducted on patients presenting to the Neurosurgery Department of Cairo University hospitals diagnosed to have either spontaneous or iatrogenic pyogenic lumbar spondylodiscitis. All cases were operated upon by surgical debridement, drainage, and posterior lumbar fixation in the same setting. Antibiotics were prescribed according to the obtained culture and sensitivity. Laboratory follow-up was done to all patients. Clinical outcome was evaluated in terms of the Denis Functional Pain Scale. Follow-up period ranged from 5 to 14 months.
\end{abstract}

Results: A total of 25 patients comprised of 15 males and 9 females with a mean age of 45.7 years (range 32-63 years) were included in this study. Nine cases had a previous lumbar discectomy surgery, and 15 cases presented with spontaneous spondylodiscitis. L4-5 level was the most frequent site of pyogenic discitis. Excellent outcome and good outcomes (score 1-3 in Denis Functional Pain Scale) were reported in 84\% of the patients and poor outcomes (score $4-5$ ) in 16\%.

Conclusion: Surgical fixation and debridement can be considered as an effective modality in the management of pyogenic lumbar spondylodiscitis with early ambulation, good control of pain, and early hospital discharge.

Keywords: Lumbar, Pyogenic, Spondylodiscitis, Debridement, Fixation

\section{Introduction}

Spondylodiscitis is a pathogenic infection of the intervertebral disc usually with secondary osteomyelitis of the adjacent end plates occurring in conjunction. The incidence of spondylodiscitis varies between 1:100,000 and 1:250,000 $[1,2]$ and represents around $3-5 \%$ of all cases of osteomyelitis [3]. However, a possible increasing incidence has been reported probably due to improved diagnostic methods, the increasing rate of surgical procedures in older polymorbid patients, and the rise in health careassociated infections [4].

* Correspondence: mrefaat_77@yahoo.co.uk

Department of Neurosurgery, Faculty of Medicine, Cairo University, El Kasr Alainy, Cairo, Egypt

\section{Springer Open}

Due to its marked heterogeneity and treatment variations, limited scientific evaluation and standard management guidelines are available [5]. The principles of treatment include eradication of the underlying infection, preservation of spinal stability, neurological deficit recovery, adequate pain therapy, and realignment in cases with spinal deformity. Antibiotic therapy, immobilization or fixation of the affected spinal segments, and debridement are essential for successful management $[3,6]$.

Due to the high rates of pseudoarthrosis and kyphotic deformation, long cure time of inflammation, and the risks of prolonged bed rest required to immobilize the affected spinal segment, conservative therapy for the management of spondylodiscitis is recently not

(c) The Author(s). 2020 Open Access This article is licensed under a Creative Commons Attribution 4.0 International License, which permits use, sharing, adaptation, distribution and reproduction in any medium or format, as long as you give appropriate credit to the original author(s) and the source, provide a link to the Creative Commons licence, and indicate if changes were made. The images or other third party material in this article are included in the article's Creative Commons licence, unless indicated otherwise in a credit line to the material. If material is not included in the article's Creative Commons licence and your intended use is not permitted by statutory regulation or exceeds the permitted use, you will need to obtain permission directly from the copyright holder. To view a copy of this licence, visit http://creativecommons.org/licenses/by/4.0/. 
considered the standard treatment unless there is contraindication of surgery [7]. Spinal immobilization often presents a challenge in conservative management as bed rest for a period of at least 6 weeks is often required [3, 8] Besides, the risks of bed rest, high rates $(16-50 \%)$ of pseudarthrosis, and instability has been reported $[2,8,9]$.

Surgical instrumented fixation of the affected segments with adequate debridement has been established as the current standard procedure. Fusion rates increased to $90-100 \%$ with reduced risk of kyphotic deformation [8, 10]. Early postoperative mobilization also reduces the risks of prolonged bed rest complications $[2,3,8]$. When compared with conservative therapy, surgical fixation and debridement offers a more safe and rapid cure of the inflammation $[3,8,11]$

The aim of this study was to evaluate the outcome of posterior lumbar spinal fixation with debridement as a treatment modality in the management of pyogenic lumbar spondylodiscitis.

\section{Patients and methods}

This is a prospective clinical study conducted on a retrospectively collected data of 25 patients diagnosed to have either spontaneous or iatrogenic pyogenic lumbar spondylodiscitis who presented to the Neurosurgery Department of Cairo University hospitals. Patients were collected over 20 months (from September 2015 to April 2017).

Spondylodiscitis was diagnosed clinically and radiologically and in laboratory. Detailed history of any previous spinal surgeries and pre-existing diseases and full clinical examination were done to all patients. Magnetic resonance imaging of the lumbar spine with gadolinium enhancement was the imaging modality used to diagnose spondylodiscitis. Laboratory blood testing of blood sedimentation rate, leukocyte, and C-reactive protein (CRP) counts was also done to diagnose and to follow-up the response of treatment in the follow-up period.

Surgical therapy was the choice of management once the diagnosis of spondylodiscitis was done. No antibiotics were given before surgery. Broad spectrum antibiotics were given after surgery till the culture and sensitivity results of the surgical biopsy was available and antibiotics were adjusted accordingly. Our protocol was to treat all patients with intravenous antibiotics for 3 weeks followed by 2 weeks of oral antibiotics. In cases with negative cultures, broad spectrum antibiotics (a combination of ceftriaxone $2 \mathrm{~g} /$ day and vancomycin $2 \mathrm{~g} /$ day) were used for 3 weeks followed by oral amoxicillin/ clavulanic acid ( $2 \mathrm{~g} /$ day) for another 2 weeks. Surgical techniques performed are as follows: adequate debridement and removal of the septic focus by discectomy and thorough curettage of the affected end plates, collection of specimens for microbiological testing, decompression of the spinal canal, with stabilization and restoration of the infected spine segment by transpedicular titanium screws with posterolateral fusion. Clinical outcome was evaluated in terms of the Denis Functional Pain Scale (Table 1) at the time of hospital discharge and in the follow-up visits. Cases had a follow-up period ranging from 5 to 14 months (mean 9.56)

\section{Results \\ Demographic data}

A total of 25 patients comprised of 16 males $(60 \%)$ and 9 females (40\%) with a mean age of 45.7 years (range $32-63$ years) were included in this study (Table 2). Ten cases $(40 \%)$ had a previous single level lumbar discectomy surgery. All patients in this group presented with severe pain after an initial postoperative pain-free interval. The initiation of symptoms postoperatively ranged from 6 to 24 days with a mean of 12.7 days. The mean interval between discectomy and establishment of diagnosis ranged from 12 to 33 days with a mean of 22.7 days. Surgeries were done when the cases were diagnosed as spondylodiscitis after laboratory and radiological assessments. Fifteen cases (60\%) presented with spontaneous spondylodiscitis. Diabetes was reported in 8 patients (32\%).

\section{Site}

L4-5 level was the most frequent site of pyogenic discitis $(52 \%)$ presenting in 6 cases in the postoperative group and in 7 cases in the spontaneous group. L3-4 level was reported in 1 case in the postoperative group and in 6 cases in the spontaneous group. L5-S1 level was detected in 3 cases in the postoperative group and in 2 cases in the spontaneous group.

\section{Presentation}

Spinal segmental pain at rest was the main presenting symptoms, and tenderness over the affected level was the main sign. General disease symptoms as fatigue and fever were reported in 9 patients in the spontaneous group and 3 patients in the postoperative group.

\section{Imaging}

Hyperintensity of the affected intervertebral disc and adjacent vertebral bodies in T2-weighted images was the

\begin{tabular}{|c|c|}
\hline Score & Criteria of pain scale \\
\hline 1 & No pain \\
\hline 2 & Minimal pain, without using medications \\
\hline 3 & Moderate pain, with occasional use of medications \\
\hline 4 & Moderate to severe pain, with constant use of medications \\
\hline 5 & Severe pain, with chronic use of medications \\
\hline
\end{tabular}


Table 2 Summary of patients' data

\begin{tabular}{|c|c|c|c|c|c|c|c|c|}
\hline & $\begin{array}{l}\text { Number } \\
\text { of } \\
\text { patients }\end{array}$ & $\begin{array}{l}\text { Demographic } \\
\text { data }\end{array}$ & Presentation & Imaging & $\begin{array}{l}\text { Laboratory } \\
\text { findings }\end{array}$ & Complications & $\begin{array}{l}\text { Hospital } \\
\text { stay }\end{array}$ & $\begin{array}{l}\text { Functional } \\
\text { outcome }\end{array}$ \\
\hline $\begin{array}{l}\text { Spontaneous } \\
\text { group }\end{array}$ & 15 & $\begin{array}{l}-9 \text { males } \\
-6 \text { females } \\
-5 \text { patients } \\
\text { (diabetics) } \\
- \text { No other co- } \\
\text { morbidities }\end{array}$ & $\begin{array}{l}\text {-Severe back pain } \\
\text {-Paravertebral muscle } \\
\text { spasm and tenderness } \\
\text {-Radiation to the buttocks, } \\
\text { thighs, and legs } \\
\text {-No motor deficits } \\
\text {-Fatigue and fever in } 9 \\
\text { patients }\end{array}$ & $\begin{array}{l}\text {-MRI: } \\
\text { hyperintensity } \\
\text { of the affected } \\
\text { levels and the } \\
\text { adjacent } \\
\text { vertebral bodies } \\
\text { in all patients } \\
\text {-CT: loss of disc } \\
\text { height and } \\
\text { endplate } \\
\text { erosion in } 9 \\
\text { cases } \\
\text {-Levels affected: } \\
\text { L3-4: } 6 \text { patients } \\
\text { L4-5:7 patients } \\
\text { L5-S1: } 2 \\
\text { patients }\end{array}$ & $\begin{array}{l}\text {-Leukocytosis } \\
\text { reported in } 8 \\
\text { patients } \\
\text {-Mean CRP at } \\
\text { the time of } \\
\text { diagnosis } \\
74.8 \mathrm{mg} / 1 \\
\text { (range } 24- \\
\text { 106) } \\
\text {-Mean ESR at } \\
\text { the time of } \\
\text { diagnosis was } \\
81.3 \text { mm/FHR } \\
\text { (range 33- } \\
124 \text { ) } \\
\text {-Pathogen } \\
\text { detected: } \\
\text { Staph. aureus: } \\
6 \\
\text { E. coli: } 4 \\
\text { No pathogen } \\
\text { could be } \\
\text { detected in } 5 \\
\text { patients }\end{array}$ & $\begin{array}{l}\text {-Superficial } \\
\text { wound } \\
\text { infection in } 3 \\
\text { patients with } \\
\text { one case } \\
\text { needing } \\
\text { secondary } \\
\text { sutures. } \\
\text {-No hardware } \\
\text { failure or } \\
\text { malposition } \\
\text { was reported. } \\
\text { - No dural tears } \\
\text { or CSF } \\
\text { leakage }\end{array}$ & $\begin{array}{l}\text { - Mean } \\
7.8 \text { days } \\
\text { (range } \\
6-11 \\
\text { days) }\end{array}$ & $\begin{array}{l}\text {-At the time } \\
\text { of hospital } \\
\text { discharge: } \\
\text { Score 1: } 2 \\
\text { patients } \\
\text { Score 3: } 9 \\
\text { patients } \\
\text { Score 4: } 4 \\
\text { patients } \\
\text {-In the } \\
\text { follow-up } \\
\text { period: } \\
\text { Score 1: } 5 \\
\text { Score 2: } 3 \\
\text { Score 3: } 4 \\
\text { Score 4: } 3 \\
\text {-Excellent } \\
\text { and good } \\
\text { outcomes: } \\
\text { 12 patients }\end{array}$ \\
\hline $\begin{array}{l}\text { latrogenic } \\
\text { group }\end{array}$ & 10 & $\begin{array}{l}-7 \text { males } \\
-3 \text { females } \\
-3 \text { patients } \\
\text { (diabetics) } \\
\text {-No other co- } \\
\text { morbidities }\end{array}$ & $\begin{array}{l}\text {-Severe back pain } \\
\text {-Para vertebral muscle } \\
\text { spasm and tenderness } \\
\text {-Radiation to the buttocks, } \\
\text { thighs, and legs } \\
\text {-No motor deficits } \\
\text {-Fatigue and fever in } 3 \\
\text { patients. Wound infection } \\
\text { with persistent wound } \\
\text { discharge in } 4 \text { patients } \\
\text { starting from the 6th to the } \\
\text { 12th day postoperative. }\end{array}$ & $\begin{array}{l}\text {-MRI: } \\
\text { hyperintensity } \\
\text { of the affected } \\
\text { levels and the } \\
\text { adjacent } \\
\text { vertebral bodies } \\
\text { in all patients } \\
\text {-CT: no Loss of } \\
\text { disc height and } \\
\text { endplate } \\
\text { erosion was } \\
\text { reported } \\
\text {-Levels affected: } \\
\text { L3-4: } 1 \text { patient } \\
\text { L4-5: } 6 \text { patients } \\
\text { L5-S1: } 3 \\
\text { patients }\end{array}$ & $\begin{array}{l}\text {-Leukocytosis } \\
\text { reported in } 6 \\
\text { patients } \\
\text {-Mean CRP at } \\
\text { the time of } \\
\text { diagnosis } \\
93.1 \mathrm{mg} / \mathrm{l} \\
\text { (range 17- } \\
115 \text { ) } \\
\text {-Mean ESR at } \\
\text { the time of } \\
\text { diagnosis was } \\
90.7 \text { mm/FHR } \\
\text { (range 52- } \\
130 \text { ) } \\
\text {-Pathogen } \\
\text { detected: } \\
\text { Staph. aureus: } \\
7 \\
\text { E. coli: } 2 \\
\text { No pathogen } \\
\text { could be } \\
\text { detected in } 1 \\
\text { patient }\end{array}$ & $\begin{array}{l}\text { Superficial } \\
\text { wound } \\
\text { infection in } 1 \\
\text { patient } \\
\text {-No hardware } \\
\text { failure or } \\
\text { malposition } \\
\text { was reported. } \\
\text {-No dural tears } \\
\text { or CSF leakage }\end{array}$ & $\begin{array}{l}\text {-Mean } \\
5.6 \text { days } \\
\text { (range 4- } \\
9 \text { days) }\end{array}$ & $\begin{array}{l}\text {-At the time } \\
\text { of hospital } \\
\text { discharge: } \\
\text { Score 2: } 2 \\
\text { patient } \\
\text { Score 3: } 5 \\
\text { patients } \\
\text { Score 4: } 3 \\
\text { patients } \\
\text {-In the } \\
\text { follow-up } \\
\text { period: } \\
\text { Score 1: } 4 \\
\text { Score 2: } 2 \\
\text { Score 3: } 3 \\
\text { Score 4: } 1 \\
\text { - Excellent } \\
\text { and good } \\
\text { outcomes: } \\
9 \text { patients }\end{array}$ \\
\hline
\end{tabular}

main sign in the diagnostic MRI (Figs. 1 and 2). Loss of disc height and end plate erosion were reported in 9 cases in the spontaneous group only.

\section{Laboratory markers}

Laboratory inflammatory markers (CRP and ESR) were elevated in all cases. Leucocytosis was present in only 14 cases (56\%). CRP returned to normal after 8-17 days (mean 12) of surgery in the surgical group and after 1327 days (mean 18.8) of surgery in the spontaneous group. A pathogen was detected in 19 cases (76\%) with
Staphylococcus aureus being the most common (52\%) and followed by Escherichia coli (24\%).

Cases had a follow-up period ranging from 5 to 14 months (mean 9.24 months); all patients were followed up after discharge every 2 weeks in the first 2 months and then monthly. The follow-up was conducted in the out-patient clinic, and the functional outcome was assessed according to Denis functional scale applied by the surgeon. Follow-up imaging in the form of $x$-rays was done in the immediate postoperative period in the hospital and every 2 months after surgery to check the integrity of the hardware. 


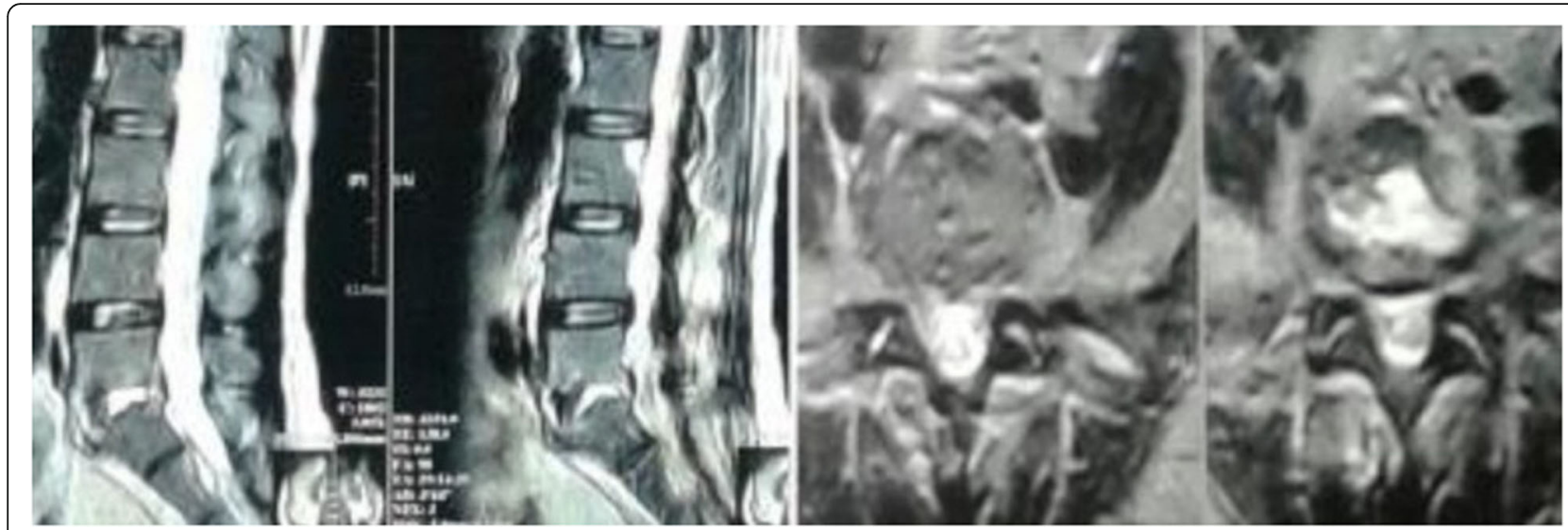

Fig. 1 T2-weighted MRI of a 43-year-old male presenting with spontaneous L5/S1 discitis. Operated upon by debridement and fusion, showed improvement from Denis 4 to Denis 1

\section{Denis functional pain scale}

Score 3 in the Denis functional pain scale was reported in 5 patients in the postoperative group at the time of hospital discharge and score 4 in 3 patients and score 2 in 1 patient. In the follow-up assessment of the postoperative group, score 1 was reported in 3 patients, score 2 in 2 patients, score 3 in 3 patients, and score 4 in 1 patient. The mean hospital stay in this group of patients was 5.6 days (range $4-9$ days).

In the spontaneous group, score 3 was present in 9 patients, score 4 in 4 patients, and score 1 in 2 patients at the time of hospital discharge. In the follow-up assessment, score 1 was reported in 6 patients, score 2 in 3 patients, score 3 in 4 patients, and score 4 in 2 patients. The mean hospital stay was 7.8 days (range 6-11 days).

Excellent outcome and good outcomes (score 1-3 in Denis functional pain scale) was reported in 21 patients (84\%) and poor outcomes (score 4-5) in 16\%.

\section{Discussion}

Spondylodiscitis is uncommon, and because of the nonspecific initial symptoms and signs, a delay of diagnosis and treatment usually occurs $[1,2,8]$. Due to its heterogenicity, literature offers no standardized guidelines for its management [5]. Due to the high rates of pseudarthrosis and kyphotic deformation, long cure time of inflammation, and the risks of prolonged bed rest required to immobilize the affected spinal segment, conservative therapy for the management of spondylodiscitis is recently not considered the standard treatment unless there is contraindication of surgery $[2,3,8,9]$.

Surgical treatment with instrumented fixation and adequate debridement and excision of the septic focus is being recently considered the standard management of spondylodiscitis $[8,10]$. Moreover, surgical biopsy remains the most reliable method for antigen detection with rate up to $68-93 \%$, [12, 13] compared to blood
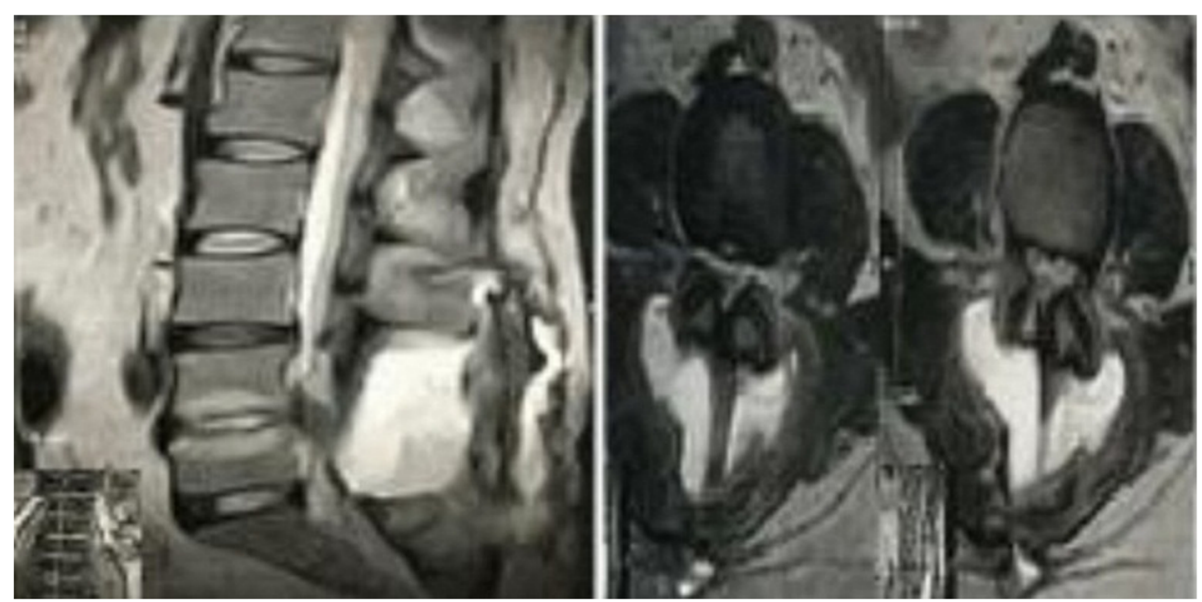

Fig. 2 T2-weighted MRI of a 50-year-old female presenting with iatrogenic $L 4 / 5$ discitis. Operated upon by debridement and fusion, showed improvement from Denis 5 to Denis 2 
cultures (25-59\%) and CT-guided biopsies (19-30\%) $[14,15]$.

As regards the benefits of the surgical therapy of spondylodiscitis over the conservative therapy, and that immobilization or fixation of the affected spinal segment is mandatory for cure achievement and pain control, we preferred adding instrumental fixation to our surgical debridement even in the absence of spinal instability and deformities. Moreover, decompression laminectomy alone destabilizing the intact posterior structures of the affected spinal level can lead to further spinal instability and deformation $[2,16]$.

Spinal instrumentation in the presence of pyogenic infection theoretically carries the risk of pathogenic colonization and persistence of infection. However, instrumentation can be applied safely and successfully by ensuring adequate debridement of the infected disc material and bone with local antibiotic application [3]. In our study, there were no cases reported of persistent infection or hardware failure in the follow-up period. Surgical complications were reported more in elderly patients ( $>65$ years old) with complication rates up to $40.6 \%$ [7]. This was not observed in our study as the patients' ages in this study were younger than 65 years old.

Pain control was achieved more rapid than inflammation cure with excellent and good clinical outcomes reported by the time of hospital discharge in 17 patients (68\%) and increased to 21 patients (84\%) in the followup period. This is probably attributed to the early surgical debridement and fixation and the rapid postoperative mobilization.

\section{Conclusion}

Surgical fixation and debridement can be considered as an effective and safe modality in the management of pyogenic lumbar spondylodiscitis with early ambulation, good control of pain, and early hospital discharge.

\section{Abbreviations}

CRP: C-reactive protein; ESR: Erythrocyte sedimentation day

\section{Acknowledgements}

Not applicable.

\section{Authors' contributions}

Both authors participated evenly in this research, and both operated the cases, participated in the data analysis, and writing of the manuscript. Also, both authors gave the final approval for this version to be published. Author MIR initiated the idea of this research, designed the research, and participated in data analysis. Author OYA participated in the data collection and analysis, did the literature review, and wrote and revised the manuscript.

\section{Funding}

This research was self-funded by the authors. Surgeries were performed in Cairo University Hospital, which is a free public educational hospital.

\section{Availability of data and materials}

All data included in this study is available for sharing, including the master table. It can be requested from the corresponding author upon request.

\section{Ethics approval and consent to participate}

This study was conducted prospectively from a retrospectively collected data from our archived data, so we did not need ethics approval. All cases included in the study had previously signed consent before surgical intervention and new consent for participation in the study was obtained upon collecting the follow up data.

\section{Consent for publication}

Not applicable.

\section{Competing interests}

The authors declare that they have no competing interests.

Received: 19 November 2018 Accepted: 18 November 2020

Published online: 30 November 2020

\section{References}

1. Butler JS, Shelly MJ, Timlin M, Powderly WG, O'Byrne JM. Nontuberculous pyogenic spinal infection in adults: a 12-year experience from a tertiary referral center. Spine. 2006:31:2695-700.

2. Frangen TM, Kalicke T, Gottwald M, Andereya S, Andress HJ, Russe OJ, Muller EJ, Muhr G, Schinkel C. Surgical management of spondylodiscitis. An analysis of 78 cases. Unfallchirurg. 2006;109:743-53.

3. Sobottke R, Seifert H, Fatkenheuer G, Schmidt M, Gossmann A, Eysel P. Current diagnosis and treatment of spondylodiscitis. Dtsch Arztebl Int. 2008; 105:181-7.

4. Statistisches Bundesamt: Diagnosedaten der Krankenhäuser ab 2000 (Eckdaten der vollstationären Patienten und Patientinnen). Gliederungsmerkmale: Jahre, Behandlungs-Mohnort, ICD10. Statistisches Bundesamt 2017.

5. Gouliouris T, Aliyu SH, Brown NM. Spondylodiscitis: update on diagnosis and management. J Antimicrob Chemother. 2010;65(Suppl 3):ii11-24.

6. Cheung WY, Luk KDK. Pyogenic spondylitis. Int Orthop. 2012;36:397-404.

7. Sobottke R, Rollinghoff M, Zarghooni K, Schluter-Brust K, Delank KS, Seifert $\mathrm{H}$, Zweig T, Eysel P. Spondylodiscitis in the elderly patient: clinical mid-term results and quality of life. Arch Orthop Trauma Surg. 2010;130:1083-91.

8. Klockner $C$, Valencia R, Weber U. Alignment of the sagittal profile after surgical therapy of nonspecific destructive spondylodiscitis: ventral or ventrodorsal method - a comparison of outcomes. Orthopade. 2001:30:965-76.

9. Flamme $\mathrm{CH}$, Frischalowski T, Gosse F. Possibilities and limits of conservative therapy of spondylitis and spondylodiscitis. Z Rheumatol. 2000;59:233-9.

10. Krodel A, Sturz H. Differentiated surgical and conservative treatment of spondylitis and spondylodiscitis. Z Orthop Ihre Grenzgeb. 1989;127:587-96.

11. Eysel P, Hopf C, Vogel I, Rompe JD. Primary stable anterior instrumentation or dorsoventral spondylodesis in spondylodiscitis? Results of a comparative study. Eur Spine J. 1997;6:152-7.

12. Nolla JM, Ariza J, Gomez-Vaquero C, Fiter J. Spontaneous pyogenic vertebral osteomyelitis in non-drug-users. Semin Arthritis Rheum. 2002;31:271-8.

13. Fleege C, Wichelhaus TA, Rauschmann MA. Systemic and local antibiotic therapy of conservative and operative treatment of spondylodiscitis. Orthopäde. 2012:41:727-35.

14. Sehn JK, Gilula LA. Percutaneous needle biopsy in diagnosis and identification of causative organisms in cases of suspected vertebral osteomyelitis. Eur J Radiol. 2012;81:940-6.

15. Garg V, Kosmas C, Young PC, Togaru UK, Robbin MR. Computed tomography-guided percutaneous biopsy for vertebral osteomyelitis: a department's experience. Neurosurg Focus. 2014;37:E10.

16. Muller EJ, Russe OJ, Muhr G. Osteomyelitis of the spine. Orthopade. 2004;33: 305-15.

\section{Publisher's Note}

Springer Nature remains neutral with regard to jurisdictional claims in published maps and institutional affiliations. 